\title{
Quality of life evaluation of frail elderly in Campinas, São Paulo
}

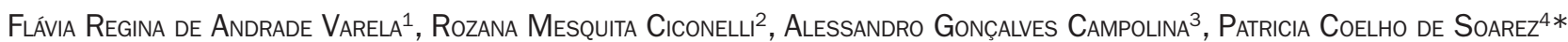 \\ ${ }^{1}$ Graduate Program in Management and Health Information Technology, Escola Paulista de Medicina, Universidade Federal de São Paulo (Unifesp), São Paulo, SP, Brazil \\ ${ }^{2}$ Escola Paulista de Medicina, Unifesp, São Paulo, SP, Brazil \\ ${ }^{3}$ Instituto do Câncer do Estado de São Paulo, São Paulo, SP, Brazi \\ ${ }^{4}$ Departament of Preventive Medicine, Faculdade de Medicina, Universidade de São Paulo (FMUSP), São Paulo, SP, Brazil
}

Study conducted at Departament of Preventive Medicine, Faculdade de Medicina, Universidade de São Paulo, São Paulo, SP, Brazil

Article received: $4 / 11 / 2014$ Accepted for publication: 9/16/2014

*Correspondence: Address: Av. Dr. Arnaldo, 455 São Paulo, SP - Brazil Postal code: 01246-903 Phone: + 551130618610 patricia.soarez@usp.br

http://dx.doi.org/10.1590/1806-9282.61.05.423

Financial support: Flávia Regina de Andrade Varela was a grant holder at Capes (Coordination for the Improvement of Higher Education Personnel)

\section{SUMMARY}

Objective: describe the quality of life of frail elderly assisted by the Centro de Referência à Saúde do Idoso (CRI), Campinas, São Paulo, Brazil.

Methods: the convenience sample included 122 frail elderly being treated from January 2010 to July 2011, out of a total of 668 frail elderly who were referred to the CRI after application of the brief evaluation form of the elderly, recommended by Ministry of Health, which identifies the elderly with some degree of frailty. Descriptive observational study collected data through sociodemographic questionnaire and quality of life questionnaires: WHOQOL-BREF, WHOQOLOLD and SF-36.

Results: the study included 122 frail elderly. Of these, $74.6 \%$ (91) were female, mean age 73 years, $46.7 \%$ (57) were married, $51.6 \%$ (63) had less than 3 years of schooling and $87.7 \%$ (107) reported income of one to four minimum wages. The mean total score of the WHOQOL-BREF was 56.6, the WHOQOL-OLD 57.6 and SF-36 Physical Component Summary 34.5 and Mental Component Summary 43.6.

Conclusion: knowledge of the impairment profile of quality of life among frail elderly is, therefore, essential for planning health care to this population.

Keywords: quality of life, frail elderly, health services for the elderly.

\section{INTRODUCTION}

In Brazil, there are now 20.8 million elderly people, which correspond to $10.8 \%$ of the total population, according to the Brazilian Census Bureau (IBGE, Instituto Brasileiro de Geografia e Estatística). Almost half of this group (48\%) is aged over 80 years. ${ }^{1}$ The United Nations (UN) said that Brazil will have a population contingent of 50.1 million seniors in $2050,{ }^{2}$ which is a challenge for the implementation of public policies that meet this new population profile.

The demographic transition phenomenon taking place throughout the world concerns all countries. The UN established the International Plan of Action on Ageing in 2002, to ensure that people can age with security and dignity, and that seniors can continue to participate in their societies as citizens with full rights. ${ }^{3}$

The World Health Organization (WHO) released a series of measures to promote healthy aging, highlighting those related to lifestyle (physical activity, smoking, alcohol, food quality). ${ }^{4}$

Aging can be considered as a multifactorial process involving structural, functional and biochemical neuro- biological changes, as well as environmental and social/ cultural factors that include quality of life (QoL), diet and physical [in]activity, which may characterize a person achieving healthy or diseased aging. ${ }^{5}$ This can happen in a sound manner, or involve senility processes, characterizing frail aging. ${ }^{5,6}$

"Frailty" can be understood as a multidimensional syndrome, involving interaction among biological, psychological and social factors, culminating in a heightened state of vulnerability, associated with increased risk of adverse clinical outcomes. ${ }^{7}$

Clinically, the following can be observed in frail elderly: weight loss, fatigue, decreased grip strength, decreased walking speed, limited physical activity, sarcopenia, and more. Consequences include falls, dependency, disability, decreased QoL, institutionalization and death. ${ }^{8,9}$ It is a process with a singular and complex biological basis, which cannot be explained only by senescence.

It is estimated that 10 to $25 \%$ of individuals over 65 years, and $46 \%$ of those above the age of 85 living in the community are fragile. ${ }^{6}$ Frail elderly individuals often suf- 
fer from chronic diseases and progressive loss of functional capabilities, which negatively impacts their quality of life, especially in the sense of preserving their dignity and independence. ${ }^{10}$ In Brazil, the FIBRA study evaluated 3,478 elderly persons who were part of probability samples from seven Brazilian cities, showing a prevalence of $9.1 \%$ of frail, $51.8 \%$ of pre-frail and $39.1 \%$ of nonfrail individuals. ${ }^{11}$

Concern about disability and its consequent impact on quality of life as a public health issue is justified by the rapid and intense aging of the population and the high prevalence of chronic diseases that cause functional limitations and disabilities among the elderly.,12,13

The assessment of health interventions in fragile elderly population is a challenge due to the multiple and complex character of their problems.

The evaluation of life quality in frail elderly individuals can help clarify the impact of functional limitations and dependence on the perceived QoL in this group, and to assess the performance of healthcare programs and services aimed toward them, as well as guide the creation of health policies.

Given that in Brazil, the QoL profile of frail elderly persons is still unclear, this study aimed to describe the quality of life of frail elderly in the care of the Elderly Healthcare Center for Referrals (CRI, Centro de Referência à Saúde do Idoso) of Campinas, from 2010 to 2011.

\section{Methods}

\section{Study site}

This descriptive observational study was conducted at the $\mathrm{CRI}$, in the municipality of Campinas. Located within the state of São Paulo, the city has approximately one million inhabitants, of which $8.87 \%$ (96.117) are elderly. Of these, 41.652 (43.33\%) are male, and 54.465 (56.67\%), female. Campinas is divided into five Health Districts (North, Northwest, East, South and West) and has 61 Basic Health Units, two municipal hospitals, two private hospitals, three polyclinics and 18 Centers for Referrals.

Aiming at the qualification of senior care and adaptation to the proposals of the National Policy on the Elderly, established by the Ministry of Health in 2006, Campinas began restructuring the elderly health care system in 2008.

The Municipal Health Department (SMS, Secretaria Municipal de Saúde) created a flowchart for specific care of the frail elderly, implementing a CRI with multidisciplinary and specialized assistance in a single building. Initially, the flowchart would meet spontaneous demand, and, later, a training model for primary care teams was designed to identify and assess health needs and refer frail elderly patients to the CRI. This initiative derived from a study of the population profile in the municipality, which showed growth of the elderly population, with a significant portion presenting limitations due to frailty, but still without the proper coverage of municipal health care policies.

\section{Population}

The convenience sample included 122 frail elderly ${ }^{7}$ who were treated from January 2010 to July 2011, of a total of 668 frail elderly individuals assisted by the CRI.

The elderly were referred to the CRI after completion of a brief evaluation form of the elderly recommended by the Ministry of Health. The document identifies elderly people with some degree of frailty that should be referred to the CRI. ${ }^{6}$ This provides a summary of the multidimensional assessment of the elderly, involving the family and the community in which the person is located. It also quantifies the overall degree of functional impairment and identifies the presence of dysfunction in the main physiological systems. Elderly people with mild/moderate dementia, Parkinson's disease, stroke in the last 12 months, one or more hospitalizations, who use at least five drugs, or present at least one functional change (related to nutrition, mood/depression, cognition/memory, strength in the arms and legs, performance of dailylife activities and the occurrence of falls in the previous year) are automatically included.

\section{Data collection}

Questionnaires administered in an interview format: (1) socio-demographic data, including gender, age, education, income and marital status; and application of the Brazilian version of the following questionnaires: (2) World Health Organization Quality of Life-BREF (WHOQOL-BREF), (3) World Health Organization Quality of Life-OLD (WHOQOL-OLD) and (4) Medical Outcomes Study 36 - item Short Form Health Survey (SF-36) to frail elderly individuals who started follow-up at the CRI. The questionnaires were administered by three interviewers trained for the task.

\section{Instruments for assessing quality of life}

The WHOQOL-BREF is a shorter version of the original instrument, WHOQOL (with 100 questions). It consists of 26 questions, two general and 24 covering four domains: physical; psychological; social relations; and the environment. In each domain, scores range from zero (worst possible score) to 100 (best possible score). ${ }^{14}$ Developed in the late 1990s, it is currently available in approximately 20 languages, including Brazilian Portuguese. ${ }^{15}$ 
The WHOQOL-OLD is a WHOQOL module specific for elderly adults and includes six domains: sensory functioning; autonomy; past, present and future activities; social participation; death and dying, and intimacy. Each domain has four items with a score that can range from 4 to 20 points. The raw scores can be processed on a scale of 0 (the lowest possible value) to 100 (highest possible). The score from the six domains can be combined to produce an overall ("global") score of quality of life for elderly adults, indicated as the "total score" of the WHOQOL-OLD module. ${ }^{16}$ The validated Brazilian version of the instrument has shown satisfactory psychometric properties: internal consistency (Cronbach's Alpha of 0.71 to 0.88 ) and test-retest (correlation coefficients between 0.58 and 0.82$).{ }^{17}$

The SF-36 version 1 comprises 11 questions and 36 items, gathered in eight domains: functional capacity (ten items); physical aspects (four items); pain (two items); general health status (five items); vitality (four items); social aspects (two items); emotional aspects (three items); mental health (five items) and a comparative question on the perception of health now and a year ago. In each area, the items are added to reflect a scale from 0 (worst health) to 100 (best health) points. ${ }^{18,19}$ The SF-36 is one of the most used generic instruments of quality life in the world. It was developed in the late 1980s in the United States and validated in Brazil in 1997. The Brazilian version showed satisfactory psychometric properties and was adapted to the socioeconomic and cultural conditions of the population. ${ }^{20}$

\section{Statistical analysis}

For the WHOQOL-BREF and WHOQOL-OLD instruments, encodings and specific guidelines of score calculation were applied according to the WHO Manual. ${ }^{21}$

For the SF-36, the guidelines in the user manual published by QualityMetric ${ }^{22}$ were used.

Descriptive statistics were applied, with reporting of relative and absolute frequency of the questions, mean, standard deviation and confidence interval.

Linear regression revealed an association between sociodemographic characteristics and domains in the quality of life questionnaires. $\mathrm{P}$ values below 0.05 , with beta (power) at 0.80 , were considered significant. Data were analyzed using Stata software version 12.1 (Copyright 1985-2011, StataCorp).

\section{Ethical matters}

Project authorized by the Research Ethics Committee of Universidade Federal de São Paulo (Unifesp) on 9/17/10 (CEP 1135/10). The participants agreed to participate in the study by signing the informed consent form.

\section{Results}

Interviews were conducted with 149 patients being followed in the CRI. Of these, ten refused to complete the three questionnaires referring fatigue and/or indisposition; 12 had their participation limited by their carers (not able to wait until the time set for the interview), and five were interrupted while answering the questionnaires to undergo health procedures and did not resume the interview after care. A total of 122 frail elderly completed the questionnaires.

Of these, $25.4 \%$ (31) were male, and $74.6 \%$ (91), female. The average age was 73 years, with standard deviation of 7.5. Approximately $46.7 \%$ (57) were married, $51.6 \%$ (63) reported having up to three years of formal education, and $87.7 \%$ (107) reported income from one to four minimum salaries (Table 1).

TABLE 1 Sociodemographic characteristics of the frail elderly, Campinas - SP, 2011.

n $\quad(\%)$

\begin{tabular}{|c|c|c|}
\hline Gender & & \\
\hline Male & 31 & 25.4 \\
\hline Female & 91 & 74.6 \\
\hline Age (mean/SD) & 73 & 7.5 \\
\hline \multicolumn{3}{|l|}{ Marital status } \\
\hline Single & 11 & 9.0 \\
\hline Married & 57 & 46.7 \\
\hline Divorced & 9 & 7.3 \\
\hline Widowed & 45 & 36.8 \\
\hline \multicolumn{3}{|c|}{ Level of education (years) } \\
\hline 0 to 3 & 63 & 51.6 \\
\hline 4 to 8 & 46 & 37.7 \\
\hline$\geq 9$ years & 13 & 10.6 \\
\hline \multicolumn{3}{|l|}{ Income } \\
\hline$<1$ minimum salary ${ }^{\dagger}$ & 11 & 9.0 \\
\hline 1 to 4 minimum salaries & 107 & 87.7 \\
\hline$>4$ minimum salaries & 4 & 3.2 \\
\hline
\end{tabular}

There were difficulties previously described in the literature for the application of the WHOQOL-BREF, WHOQOLOLD and SF-36 questionnaires to the frail elderly population. These were related to the very application of the questionnaires ${ }^{23-25}$ and the studied population. Cognitive and physical conditions of the elderly limited participation in the research. The presence of a caregiver attentive to the needs of the frail elderly at the interview proved to be essential for adherence and participation in the research. 
Quality of life as measured using the WHOQOL-BREF

The average total score was 56.6 (standard deviation = 11.2; Min/Max 3.5/87.7). The physical and environment domains showed the worst scores, 44.8 and 54.0, respectively (Table 2).

TABLE 2 Results of the domains in the WHOQOL-BREF questionnaire.

\begin{tabular}{llll} 
Domains & Mean & $\begin{array}{l}\text { Standard } \\
\text { deviation }\end{array}$ & Minimum/maximum \\
\hline Physical & 44.8 & 18.4 & $3.6-85.7$ \\
\hline Psychological & 60.0 & 14.4 & $16.7-87.5$ \\
\hline Social relations & 67.3 & 13.3 & $16.7-100$ \\
\hline Environment & 54.0 & 11.1 & $18.8-81.3$ \\
\hline General & 56.6 & 11.2 & $17.6-79.5$ \\
\hline
\end{tabular}

Statistically significant association was found between the total score of the WHOQOL-BREF and education $(\mathrm{p}=0.014)$, and marital status $(\mathrm{p}=0.005)$ (Table 3$)$. Married participants and with more years of formal education had better scores for quality of life.

TABLE 3 Association between domain scores in the WHOQOL-BREF and answers regarding education, income and marital status.

\begin{tabular}{|c|c|c|c|c|}
\hline & Coefficient & $\mathbf{t}$ & $95 \mathrm{Cl}$ & $p>|t|$ \\
\hline Domains & 64.97 & 10.04 & $52-78$ & 0.000 \\
\hline Education & 3.72 & 1.5 & $0.78-6.6$ & 0.014 \\
\hline Income & -4.17 & -1.42 & $-10-1.66$ & 0.159 \\
\hline Marital status & -3.33 & -2.89 & $-5.6-1.05$ & 0.005 \\
\hline
\end{tabular}

In the physical domain, $31.9 \%$ (39) rated their walking ability as bad and were dissatisfied with their ability to perform activities of daily life and work (31.9 and 40.9\%, respectively). Approximately $55.7 \%$ (68) reported that they needed very little medical treatment to live their daily lives; $44.9 \%$ (54) reported that they were satisfied with their sleep, and $45 \%$ (55) had enough energy to carry on with their daily routines.

In the psychological domain, 37.7\% (46) said they enjoy life moderately, $52.2 \%$ (64) believed that it has enough meaning, $55.74 \%$ (68) accepted their physical appearance and $74.5 \%$ (91) were satisfied with themselves. On the other hand, $43.4 \%$ (53) had negative feelings very often.

Respondents seemed to be satisfied with the items in the social relations domain, so that $69.6 \%$ (85) reported being satisfied with their personal relations, $63.9 \%$ (78) were happy with their sex lives, and $77.0 \%$ (94) were satisfied with the support they receive from friends.

Regarding the environment domain, $67.2 \%$ (76) were satisfied with the access and $62.3 \%$ (82) with the transport they used. On the other hand, 55.7\% (68) reported having very little money to meet their needs, and having very few recreational opportunities.

Quality of life as measured using the WHOQOL-OLD The average total score of WHOQOL-OLD was 58 (standard deviation $=11$; 95CI 56-60). Domains autonomy and social participation showed the worst scores: 47.9 and 49.2, respectively.

Statistically significant positive association was found between the WHOQOL-OLD scores and formal education $(\mathrm{p}=0.015)$ - the higher the education, the better the quality of life.

With the results of domain sensory functioning, we were able to see that sensory loss (hearing, sight, taste, smell and touch) has an impact on the quality of life: $28.6 \%$ (35) reported that their ability to perform activities was severely impaired, while $38.5 \%$ (47) said that having restricted senses completely affects their interaction with others.

As for domain autonomy, $41.8 \%$ (51) said they were quite free to make their own decisions, and 52.4\% (64) felt respected by people around regarding their freedom. On the other hand, $31.1 \%$ (38) do not feel in control of their future, and $49.1 \%$ (60) say they can rarely do what they would like to.

Regarding post, present and future activities, 40.1\% (49) believe that they received the recognition they deserved in life, and $76.2 \%$ (93) felt satisfied with what we have achieved; however, as to what can still be achieved, 48.3\% (59) say they are more or less satisfied with the new possibilities. Overall, $48.3 \%$ (59) felt happy with the prospects.

In the domain social participation, $55.7 \%$ (68) felt they have just enough to do what they want on a daily basis, and $51.6 \%$ (63) felt satisfied with the way in which they use their time. On the other hand, $44.2 \%$ (54) and $41.8 \%$ (51), respectively, said that they are dissatisfied with their level of activity and opportunities to take part in activities within the community.

In the domain death and dying, $72.1 \%$ (88) expressed extreme fear of dying, $61.4 \%$ (75) expressed extreme fear of not controlling death, and $63.1 \%$ (77) were extremely concerned about the way they will die.

Responses to domain intimacy showed a positive view of feelings of love/being loved. More than half of respondents had the opportunity to love and be loved (55.74\% 
and $50.82 \%$, respectively), and to feel love in their lives (63.11\%, or 77 individuals).

Quality of life as measured using the SF-36

Mean total scores ranged from 29.3 to 61.0. The highest score was obtained in the domain general health (61.0), followed by mental health (56.5), social functioning (55.3), pain (48.4), vitality (48.1), emotional aspects (44.2), physical aspects (37.2) and, last, functional capacity (29.3) (Table 4).

\begin{tabular}{|c|c|c|c|}
\hline Domains & Mean & $\begin{array}{l}\text { Standard } \\
\text { deviation }\end{array}$ & Minimum/Maximum \\
\hline $\begin{array}{l}\text { Sensory } \\
\text { functioning }\end{array}$ & 61.3 & 22.7 & $0-100$ \\
\hline Autonomy & 47.9 & 17.0 & $12.5-93.7$ \\
\hline $\begin{array}{l}\text { Past, present and } \\
\text { future activities }\end{array}$ & 57.8 & 12.9 & $18.7-81.2$ \\
\hline $\begin{array}{l}\text { Social } \\
\text { participation }\end{array}$ & 49.2 & 17.4 & $6.2-81.2$ \\
\hline Death and dying & 68.4 & 22.8 & $6.2-81.2$ \\
\hline Intimacy & 61.0 & 15.9 & $12.5-100$ \\
\hline Total score & 57.6 & 11.1 & $31.3-80.3$ \\
\hline
\end{tabular}

Association between the scores of the SF-36 and sociodemographic characteristics, namely, education, income and marital status, showed statistical significance only with marital status $(\mathrm{p}=0.004)$. Married individuals had higher scores for quality of life.

\section{Discussion}

The evaluation of quality of life of frail elderly individuals is an important outcome to be measured in research involving the geriatric population. Elderly patients usually suffer from chronic diseases and increasing disability, and many of the therapeutic approaches in this age group aim to alleviate the suffering and improve the functional status of patients. ${ }^{26}$ Assessing the quality of life of individuals attending a service dedicated exclusively to this population can, therefore, provide important information for the development of health policies that address the actual health needs of the frail elderly.

In this sense, the combination of generic questionnaires (WHOQOL-BREF and SF-36) with a specific tool for the condition of interest (WHOQOL-OLD) is one of the recommended strategies to widely assess the quality of life and was adopted in this study. Although there are no specific questionnaires for the frail elderly, the appli- cation of the tools has proved to be valid in other populations of similar age. ${ }^{27}$

First, as to the socio-demographic profile of the population studied, there is a trend already described in the literature: the feminization of aging (6.23), with $74.6 \%$ (91) of the respondents being female. The scientific literature has shown that women in general, despite having a longer life expectancy than men, have shorter disability-free periods than the male population, which suggests a difference in quality of life based on gender. The factors commonly mentioned to explain the lower quality of life among women are related to differences in social opportunities between the two sexes and the highest mortality at a lower age for men. ${ }^{28}$

The average age of respondents was 73 years with a significant number of patients between 70 and 80 years. In a Brazilian study that assessed the quality of life of older adults seen at a tertiary eye care service, the average age was 71.6 years, also predominantly female (51.3\%). ${ }^{25}$ Another Brazilian study that included 1,950 elderly persons from a community also displayed female prevalence $(57.2 \%)$, with $58.9 \%$ being married, $42.6 \%$ with up to three years of formal education, and income predominantly between one and four minimum salaries $(51.8 \%) .{ }^{29}$ In this service, most of the patients stated income from one to four minimum wages (87\%). A Canadian study that included a similar population, the average age was 78.5 years, ranging from 63 to 98 years, with a predominance of married individuals (45\%), followed by widowed (43\%). ${ }^{26}$ At the CRI, similar figures were found, with $46.72 \%$ of married participants and a smaller percentage of widowed, $36.89 \%$.

The influence of sociodemographic factors on quality of life was assessed using regression analysis, which showed that married and more educated subjects had better scores on the WHOQOL-BREF. Other Brazilian studies also showed the influence of these factors on quality of life of older adults, highlighting worsening of quality of life among elderly women with lower income and less education. ${ }^{29,30}$

Impaired functional capacity was demonstrated in this population by low scores in the physical domains of WHOQOL-BREF (44.8), autonomy in the WHOQOLOLD (47.9) questionnaire, and functional capacity in the SF-36 (29.3). A Brazilian study showed that the prevalence of disability is generally higher in women, and the risk of disability doubles every decade of life. ${ }^{24}$ The same study showed that functional capacity is strongly influenced by the per capita household income, which was also observed in the elderly under the care of the CRI. Other 
studies conducted in the Brazilian context have shown that functional capacity is a central aspect of quality of life in the elderly. ${ }^{25,30-32}$ Maintain or regain the ability to walk, and hence capacity for work, can therefore have a positive impact on the perception of quality of life in this population.

Compared to other Brazilian studies, the deterioration of the quality of the senses did not have such a strong impact on quality of life among the frail elderly treated at the CRI. The score pertaining to domain sensory functioning in the WHOQOL-OLD totaled 61.3, much higher than the score obtained from Brazilian studies conducted with smaller samples: 9.7 and 14.8, respectively, including 40 elderly individuals from rural areas ${ }^{33}$ and 15 from a common social group. ${ }^{34}$ Another study that used the WHOQOL-OLD reported lower scores in the domain of sensory function (39.7). ${ }^{35}$

Perception of autonomy was the domain with the lowest score (47.9) and greater impact on the quality of life of these elderly individuals. A Brazilian study that applied the WHOQOL-OLD to a population of physically active elderly persons also showed that autonomy (59.5) was the most affected area for quality of life. The authors attributed the reduction of autonomy to the lack of public security, leisure facilities in the neighborhood and/or the precarious nature of urban transport. ${ }^{36}$ Nevertheless, if we consider that other WHOQOL-OLD domain with low scores was that of social participation, totaling 49.2 points, it is also possible that the reduction of autonomy may be associated with restrictions in social participation due to loss of functional capacity.

It is also possible that the activities proposed for the elderly population treated at the CRI are insufficient and/ or unsatisfactory. Studying these actions can, therefore, lead to a more accurate perception of quality of life in this population. In contrast, another study reported full satisfaction with activities performed in community groups, which are involved in social and religious actions that act as facilitators for interaction and development of new friendships, expanding the circle of social support. ${ }^{23}$

While the score for the domain death and dying was the highest (68.4) among our respondents, most reported being too afraid of feeling any pain in the process of death, which was also observed in other studies that used the WHOQOL-OLD. ${ }^{33-35}$ Despite the many effective drugs for pain relief, these patients are often inadequately treated, especially when the caregiver has limited access to information or is afraid to medicate, which would explain the results. There are gaps in the discussion of this issue with elderly patients, with the general population, and with society as a whole regarding regulatory issues that concern the artificial prolongation of life, which should occur in a timely manner.

The intimacy domain score (61) differs from that found in another Brazilian study that reached a lower value. The low result obtained in the other study may be associated mainly to the number of widowers, divorcees and elderly living alone in the sample. ${ }^{34}$

The results obtained with the SF-36 in the frail elderly population of the CRI were similar to those of a study conducted in a geriatric institution in Canada. ${ }^{27}$ In the latter, the married participants also presented better quality of life. In both, mental health and social aspects were among the domains that had the highest scores: 56.5/80 and 55.3/62.5, respectively. The domain with the highest score in the Canadian study was emotional aspects (100), much higher than the result found at the CRI (44.2). The frail elderly of Campinas had higher scores in the domains functional capacity, physical aspects, general health and vitality $(29.3 ; 37.2 ; 61$ and 48.1 , in this order) compared to the Canadians (15; zero; 55 and 40 , respectively). However, one must keep in mind that, since the Canadian study evaluated a population of institutionalized elderly, a greater physical and functional impairment would be expected.

A study of elderly persons living in the community in São Paulo showed higher scores in the domains of social aspects, mental health, general health and vitality (70.2, 66.4, 61.6 and 61.0, respectively) and lower scores for pain, functional capacity, emotional aspects and physical aspects $\left(59.6,58.4,56.4\right.$ and 54.4 , respectively). ${ }^{25}$ Comparing these results with those obtained from the CRI reveals that the highest scores are in agreement and reach similar points, which is not seen in the case of lower scores, which are also in agreement but distant regarding the number of points, especially for functional capacity and physical aspects (58.4 versus 29.3 and 54.4 versus 37.2 , respectively). The elderly from the CRI, being frail, had lower scores reflecting stronger impact of physical and functional aspects on their perceived quality of life. Likewise, in another population study carried out in the State of São Paulo, elderly individuals living in the community had higher scores in the domains mental health and general health status (69.9 and 70.1). ${ }^{29}$

The main limitation of this study is that the convenience sampling in a referral center may not accurately reflect the entire universe of frail elderly living in the community. However, the results can facilitate the implementation of health services in referral centers for care of the elderly population. The lack of questionnaires assessing 
quality of life, specifically in frailty syndrome that can be used in this and in other studies, prevents proper evaluation of more specific aspects of such population. The wide variety of definitions of frailty found in the scientific literature hinders a seamless interpretation of the immense body of information produced about this condition. Comparisons with other studies should, therefore, be viewed with caution.

Overall, the results obtained with the generic questionnaires showed greater impairment of physical aspects of the frail elderly. In the WHOQOL-BREF, the domain physical aspect was the most affected (44.8), while in the SF-36, functional capacity (29.3) and physical aspects were the most affected (37.2). In the specific WHOQOLOLD questionnaire, in turn, domains autonomy (47.9) and social participation (49.2) were the most relevant.

These results suggest that physical impairment of the frail elderly is an important factor for complete autonomy and social participation. Thus, public health policies for this population should prioritize the provision of services that optimize the functional performance of the elderly and promote the adequacy of home and urban environments for this population.

The increase in life expectancy is one of the greatest achievements of mankind, but the maintenance of wellbeing throughout the aging process is one of the greatest challenges of today's health care. Knowing the profile of impaired quality of life of the frail elderly is, therefore, fundamental for the planning of health care aimed at this population.

\section{Resumo}

Avaliação de qualidade de vida em idosos frágeis em Campinas, SP

Objetivo: descrever a qualidade de vida dos idosos frágeis atendidos pelo Centro de Referência à Saúde do Idoso (CRI), de Campinas, São Paulo.

Métodos: a amostra de conveniência incluiu 122 idosos frágeis, que iniciaram tratamento a partir de janeiro de 2010 até julho de 2011, de um universo de 668 idosos frágeis encaminhados ao CRI após aplicação da ficha de avaliação breve do idoso, preconizada pelo Ministério da Saúde, que identifica o idoso com algum grau de fragilidade. Estudo observacional descritivo coletou dados por meio de questionário sociodemográfico e questionários de qualidade de vida: WHOQOL-BREF, WHOQOL-OLD e SF-36.
Resultados: participaram do estudo 122 idosos frágeis. Desses, 74,6\% (91) eram do sexo feminino, com média de idade de 73 anos, 46,7\% (57) eram casados, 51,6\% (63) apresentaram até 3 anos de escolaridade e 87,7\% (107) informaram renda de um a quatro salários mínimos. O escore total médio do WHOQOL-BREF foi 56,6, o do WHOQOL-OLD, 57,6; e no SF-36 o Componente Físico Sumarizado foi 34,5 , enquanto o Componente Mental Sumarizado foi de 43,6.

Conclusão: o conhecimento do perfil de comprometimento de qualidade de vida de idosos frágeis é, portanto, fundamental para o planejamento da atenção à saúde dessa população.

Palavras-chave: qualidade de vida, idoso fragilizado, serviços de saúde para idosos.

\section{RefEREnCES}

1. Ministério da Saúde (Brasil). Departamento de Informática do SUS. O DATASUS informações de saúde (TABNET): demográficas e socioeconômicas. [cited in 1/13/2014]. Available from: http://www2.datasus.gov.br/DATASUS/ index.php? area $=0206 \& \mathrm{VObj}=$ http://tabnet.datasus.gov.br/cgi/deftohtm. exe?ibge/cnv/pop.

2. United Nations. Department economics and social affairs. Populations division World population prospects: the 2012 revision New York 2011. [cited in 1/13/2014]. Available from: http://esa.un.org/unpd/wpp/index.htm.

3. Organização das Nações Unidas. Plano de ação internacional para o envelhecimento. Brasília, 2002.

4. World Health Organization. World Health day. WHO, 2012 [cited in 1/13/2014] Available from: http:/www.who.int/world-health-day/2012/en/.

5. Santos FH, Andrade VM, Bueno OF. Envelhecimento: um processo multifatorial. Psicol Estud. 2009; 14(1):3-10. [cited in 1/13/2014]. Available from: http:/www.scielo.br/scielo.php?script=sci_arttext\&pid=S1413$73722009000100002 \&$ Ing=pt\&nrm=iso\&ting=pt.

6. Ministério da Saúde (Brasil). Secretaria de Atenção à Saúde. Departamento de Atenção Básica. Envelhecimento e saúde da pessoa idosa. Série A. Normas e Manuais Técnicos; Cadernos da Atenção Básica, n.19. Brasília, 2007.

7. Fried LP, Tangen CM, Walston J, Newman AB, Hirsch C, Gottdiener J, et al Frailty in older adults: evidence for a phenotype. J Gerontol A Biol Sci Med Sci. 2001; 56(3):M146-56

8. Silva TA, Frisoli Junior A, Pinheiro MM, Szejnfeld VL. Sarcopenia associada ao envelhecimento: aspectos etiológicos e opções terapêuticas. Rev Bras Reumatol. 2006; 46(6):391-7.

9. Rosenberg IH. Sarcopenia: origins and clinical relevance. J Nutr. 1997; 127(5 Suppl):990S-1S.

10. Bonardi G, Souza VB, Moraes JF. Incapacidade funcional e idosos: um desafio para os profissionais de saúde. Scientia Med. 2007; 17:138-44.

11. Neri AL, Yassuda MS, Araújo LF, Eulálio MoC, Cabral BE, Siqueira ME, et al. Metodologia e perfil sociodemográfico, cognitivo e de fragilidade de idosos comunitários de sete cidades brasileiras: Estudo FIBRA. Cad Saúde Pública. 2013; 29(4):778-92.

12. Pontes RJ, Ramos NA, Bosi ML. Transição demográfica e epidemiológica. In: Medronho RA, Block KV, Luiz RR, Werneck GL (eds.). Epidemiologia. 2.ed. São Paulo: Atheneu, 2009. p.123-52.

13. Ministério da Saúde (Brasil). Secretaria de Vigilância em saúde. Plano de ações estratégicas para o enfrentamento das doenças crônicas não transmissíveis (DCNT) no Brasil: 2011-2022. Série B. Textos Básicos de Saúde. Brasília, 2011.

14. Development of the World Health Organization WHOQOL-BREF quality of life assessment. The WHOQOL Group. Psychol Med. 1998; 28(3):551-8. 
15. Fleck MP, Louzada S, Xavier M, Chachamovich E, Vieira G, Santos L, et al. Aplicação da versão em português do instrumento abreviado de avaliação da qualidade de vida “WHOQOL-bref”. Rev Saúde Pública. 2000; 34(2):178-83.

16. Power M, Quinn K, Schmidt S, Group W-O. Development of the WHOQOLold module. Qual Life Res. 2005; 14(10):2197-214.

17. Fleck MP, Chachamovich E, Trentini C. Development and validation of the Portuguese version of the WHOQOL-OLD module. Rev Saúde Pública. 2006; 40(5):785-91.

18. Ware JE, Sherbourne CD. The MOS 36-item short-form health survey (SF-36). I. Conceptual framework and item selection. Med Care. 1992; 30(6):473-83.

19. Stewart AL, Hays RD, Ware JE. The MOS short-form general health survey. Reliability and validity in a patient population. Med Care. 1988; 26(7):724-35.

20. Ciconelli RM, Ferraz MB, Santos W, Meinão I, Quaresma MR. Tradução para a língua portuguesa e validação do questionário genérico de avaliação de qualidade de vida SF-36 (Brasil SF-36). Rev Bras Reumatol. 1999; 39(3):143-50.

21. Organização Mundial da Saúde. Manual WHOQOL-old/bref. Geneva: OMS, 2012.

22. 22. Ware JE, Kosinski M, Dewey JE. How to score version two of the SF-36 Health Survey. Lincoln: Quality metric, Inc; 2000.

23. Santos SR, Santos IB, Fernandes MG, Henriques ME. Qualidade de vida do idoso na comunidade: aplicação da escala de Flanagan. Rev Latinoam Enferm. 2002; 10(6):757-64.

24. Giacomin KC, Peixoto SV, Uchoa E, Lima-Costa MF. Estudo de base populacional dos fatores associados à incapacidade funcional entre idosos na Região Metropolitana de Belo Horizonte, Minas Gerais, Brasil. Cad Saúde Pública. 2008; 24(6):1260-70.

25. Campolina AG, Dini PS, Ciconelli RM. Impacto da doença crônica na qualidade de vida de idosos da comunidade em São Paulo (SP, Brasil). Ciênc Saúde Coletiva. 2011; 16(6):2919-25.

26. Guyatt GH, Eagle DJ, Sackett B, Willan A, Griffith L, McIlroy W, et al. Measuring quality of life in the frail elderly. J Clin Epidemiol. 1993; 46(12):1433-44.
27. Stadnyk K, Calder J, Rockwood K. Testing the measurement properties of the Short Form-36 Health Survey in a frail elderly population. J Clin Epidemiol. 1998; 51(10):827-35

28. Camargos MC, Perpétuo IH, Machado CJ. Expectativa de vida com incapacidade funcional em idosos em São Paulo, Brasil. Rev Panam Salud Publica. 2005; 17(5-6):379-86.

29. Lima MG, Barros MB, César CL, Goldbaum M, Carandina L, Ciconelli RM. Health related quality of life among the elderly: a population-based study using SF-36 survey. Cad Saúde Pública. 2009; 25(10):2159-67.

30. Alexandre TaS, Cordeiro RC, Ramos LR. Factors associated to quality of life in active elderly. Rev Saúde Pública. 2009; 43(4):613-21.

31. Alexandre TaS, Corona LP, Nunes DP, Santos JL, Duarte YA, Lebrão ML. Gender differences in incidence and determinants of disability in activities of daily living among elderly individuals: SABE study. Arch Gerontol Geriatr. 2012; 55(2):431-7.

32. Sonati JG, Modeneze DM, Vilarta R, Maciel ES, Boccaletto EM, da Silva CC. Body composition and quality of life (QoL) of the elderly offered by the "University Third Age" (UTA) in Brazil. Arch Gerontol Geriatr. 2011; 52(1):e31-5.

33. Alencar NA, Aragão JCB, Ferreira MA, Dantas EHM. Avaliação de qualidade de vida em idosas residentes em ambientes urbano e rural. Rev Bras Geriatr Gerontol. 2010; 13(1):101-9.

34. Serbim AK, Figueiredo AEPL. Qualidade de vida de idosos em um grupo de convivência. Scientia Med. 2011; 21(4):166-72.

35. Gutierrez BA, Auricchio AM, Medina NV. Mensuração da qualidade de vida de idosos em centros de convivência. J Health Sci Inst. 2011; 29(3):186-90.

36. Vilela JR GB, Grande AJ, Cieslak F, Leite N. Comparação de domínios de qualidade de vida em diferentes contextos em idosos. CPAQV. 2011; 3(2). [cited in 1/13/2014]. Available from: http://www.cpaqv.org/revista/CPAQV/ ojs-2.3.7/index.php/Revista/article/view/29/28. 